\title{
Bioactive and biocompatible cement as a single element in pulpotomy of deciduous teeth: a randomized clinical trials
}

\author{
Cimento bioativo e biocompativel como elemento único em pulpotomia \\ de dentes decíduos: ensaio clínico randomizado
}

\author{
Fernanda Valadão MOYSÉS ${ }^{1}$ iD https://orcid.org/0000-0002-0709-5853 \\ Daniela Francescato VEIGA ${ }^{1}$ iD https://orcid.org/0000-0002-8713-2940 \\ Marcelo Junqueira PEREIRA2 ${ }^{2}$ iD https://orcid.org/0000-0002-6769-863X \\ Matheus Henrique Lopes DOMINGUETE² ${ }^{2}$ https://orcid.org/0000-0003-2742-6848 \\ Camila Alessandra PAZZINI² ${ }^{2}$ https://orcid.org/0000-0002-1699-4682 \\ Ana Carla Junqueira PEREIRA2 ${ }^{2}$ https://orcid.org/0000-0002-4585-3256 \\ José Dias da SILVA NETO' ${ }^{\text {ID }}$ https://orcid.org/0000-0001-6166-0035
}

\section{ABSTRACT}

Objective: Pulpotomy in deciduous teeth maintains the integrity and health of deciduous teeth and supporting tissues until a permanent tooth has erupted. PBS HD CIMMO ${ }^{\circledR}$ cement was evaluated in deciduous teeth pulpotomies as base material and restoration. A randomized clinical trial was performed. Methods: This study was approved by the Ethics Committee of (Universidade Vale do Sapucaí) UNIVÁS with Certificate of Presentation for Ethical Consideration, protocol number is: 1.771.929. 60 deciduous molar teeth from 32 healthy children were selected. These teeth were divided into two groups: G1 with 30 teeth, in which the classictreatment with formocresol was used, and G2 with 30 teeth, in which PBS HD CIMMO ${ }^{\circledR}$ cement was used as base and simultaneous final restoration. The evaluation was performed 12 months after the intervention through clinical and radiographic exams. Fisher's exact test was performed to correlate the clinical and radiographic aspects in both groups. Results: There was no significant difference ( $p=0.090$ ) in the clinical-radiographic evaluation. PBS HD CIMMO ${ }^{\circledR}$ cement is option to be used as a single element in pulpotomies of deciduous teeth. Conclusion: Longitudinal studies should be performed in order to demonstrate a significant association between these groups. The study was enrolled in clinical trials (clinical trials.gov) with registration NCT03200938.

Indexing terms: Pediatric dentistry. Pulpotomy. Biocompatible materials.

\section{RESUMO}

Objetivos: A pulpotomia em dentes decíduos mantém a integridade e a saúde dos dentes decíduos e dos tecidos de suporte, até a erupção de um dente permanente. O cimento PBS HD CIMMO ${ }^{\circledR}$ foi avaliado em pulpotomias de dentes decíduos como material

$\boldsymbol{\nabla} \boldsymbol{\nabla} \nabla$

1 Universidade do Vale do Sapucaí, Mestrado profissional em Ciências Aplicadas à Saúde. Av. Prefeito Tuany Toledo, 470, Fátima I, 37554-210, Pouso Alegre, MG, Brasil. Correspondence to: JD SILVA NETO. E-mail: <jdendod@yahoo.com.br>.

2 Universidade Vale do Rio Verde, Faculdade de Odontologia. Três Corações, MG, Brasil.

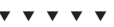

How to cite this article

Moysés FV, Veiga DF, Pereira MJ, Dominguete MHL, Pazzini CA, Pereira ACJ, et al. Bioactive and biocompatible cement as a single element in pulpotomy of deciduous teeth: a randomized clinical trials. RGO, Rev Gaúch Odontol. 2020;68:e20200028. http://dx.doi.org/10.1590/1981863720200002820180081 
de base e restauração. Um ensaio clínico randomizado foi realizado. Métodos: Este estudo foi aprovado pelo Comitê de Ética da Universidade Vale do Sapucaí, UNIVÁS, com Certificado de Apresentação para Consideração Ética, número do protocolo: 1.771.929. Foram selecionados 60 dentes molares decíduos de 32 crianças saudáveis. Esses dentes foram divididos em dois grupos: G1 com 30 dentes, no qual foi utilizado o tratamento clássico com formocresol e G2 com 30 dentes, no qual o cimento PBS HD CIMMO ${ }^{\circledR}$ foi utilizado como base e restauração final simultânea. A avaliação foi realizada 12 meses após a intervenção através de exames clínicos e radiográficos. O teste exato de Fisher foi utilizado para correlacionar os aspectos clínicos e radiográficos nos dois grupos. Resultados: Não houve diferença significativa $(p=0,090)$ na avaliação clínico-radiográfica. O cimento PBS HD CIMMO ${ }^{\circledR}$ é uma opção para ser usado como um elemento único em pulpotomias de dentes decíduos. Conclusão: Estudos longitudinais devem ser realizados para demonstrar uma associação significativa entre esses grupos. O estudo foi inscrito em ensaios clínicos (Clinical Trials.gov) com o registro NCT03200938.

Termos de indexação: Odontopediatria. Pulpotomia. Materiais biocompatíveis.

\section{INTRODUCTION}

Pulpotomy in deciduous teeth consists of removal of the coronary pulp due to extensive carious process without evidence of root pathology. The etiology of exposure determines pulpal response, making it crucial to distinguish between mechanical and carious exposures. The carious exposure is resumed to be accompanied by severe inflammation, which makes the prognosis of treatment unpredictable. Biomaterials can be used especially in cases with carious pulp exposures [1]. The primary purpose of pulpotomy is to maintain the integrity and health of deciduous teeth and supporting tissues until a permanent tooth has erupted. In this technique, the remaining pulp is maintained with vitality and is free of any pathological alterations [1-3].

Formocresol (FC), idealized by Buckley in 1904, is considered the gold standard product due to its bacteriostatic and fixative properties and is the agent most frequently used in pulpotomy [3]. However, FC is composed of formaldehyde, which has mutagenic, carcinogenic action and cresol, which is a caustic agent. Cements, such as zinc oxide and eugenol, are used due to the absence of a material with bio-compatible and bioactive properties, which can be installed directly on the exposed wound on the entrance of the root canals [4]. The occurrence of internal resorption may be attributed to the use of zinc oxide and eugenol (ZOE) as a sub-base, since the eugenol is irritant and may cause a subclinical chronic inflammation. Moreover, other factors are related to this alteration, such as inadequate bleeding control and clot formation, as well as improper restorations with failed sealing, allowing bacterial infiltration and pulp inflammation [5]. The objective of this study was to use in pulpotomies of deciduous teeth, cement not yet used for this indication.
The advent of biological cements signaled a new era in odontology. These cements are biocompatible and bioactive alternatives for use in procedures in which a conventional technique is limited [6,7]. The biological cements exclude the use of drugs, such as formocresol, summarizing the technique in the removal of the coronary pulp, hemostasis and cement installation. MTA (mineral trioxide aggregate), Biodentine TM (Septodont, St. Maur des Fosses) and PBS HD CIMMO ${ }^{\circledR}$ cement are several examples of bioactive cements [6-8].

Recent studies determined the development of biological cement with the same base as MTA and Biodentine, but with additives (natural elements responsible for the increase of cement resistance) and without radiopacifier, an element that interferes with the resistance of cement, which is an important requirement, owing to the masticatory forces. This cement is the PBS HD CIMMO ${ }^{\circledR}$ $[6,7,9-11]$. The physical and biological properties of this cement justify its use in pulpotomies of deciduous teeth.

\section{METHODS}

This report describes a two-armed randomized clinical trial with an allocation ratio of $1: 1$, which was approved by the Ethics Committee of UNIVÁS protocol number is: 1.771.929. The trial was registered at ClinicalTrials.gov (NCT03200938). The study locations were the Universidade Vale do Sapucaí (UNIVAS) Pouso Alegre, Minas Gerais, Brazil, and Universidade Vale do Rio Verde (UNINCOR) Três Corações, Minas Gerais, Brazil.

A sample size of 60 teeth (30 per group) was calculated, assuming 90\% statistical power for detection. This sample size was calculated based on the proportion of $71 \%$ successful pulpotomy treatment with formocreso [12], considering an expected proportion of success of $90 \%$ for treatment with $\mathrm{PBS} \mathrm{HD} \mathrm{CIMMO}^{\circledR}[6,7,9,10$, 
11]. A recent study determined that the combined success rate for all pulpotomies was 82.6 percent based on 1,022 teeth. Mineral trioxide aggregates (MTA) (89.6 percent) and formocresol (FC) (85.0 percent) were the highest of all pulpotomy types and were not significantly different $(P=0.15)$, with high quality of evidence. "In this way, the possibility of using the bioceramic PBS HD, similar to the MTA, justifies the calculation of the sample [12].

Patients who met the inclusion and non-inclusion criteria and had provided signed informed consent (free and informed consent form) were eligible for the study. The sample consisted of 60 deciduous molar teeth from 32 patients aged 3 to 8 years, of both sexes. The selection of the cases, the follow-up of the interventions and the preservations were carried out by the Teachers of the Pediatric Dentistry Clinic of UNINCOR. The treatments were carried out by students from the 8th period of dentistry. The selected teeth had indication for pulpotomy through anamnesis, clinical and radiographic examination.

The inclusion criteria for the teeth were: absence of spontaneous painful symptomatology in the preoperative period, evidence of healthy pulp and free from injuries, and hemostasis after the cut of the coronary pulp. The radiographic images of the selected teeth presented $2 / 3$ of the root length, absence of hypodense interradicular lesion and internal root resorption. The exclusion criteria were the following patients who presented fistula in the periapical region of the tooth and radiographic images indicative of periapical lesions at initial examination.

The random allocation sequence was generated by the Random Excel $4.0^{\circledR}$ software (Microsoft Corporation, USA), and a service order was defined using a random number table classified from 1 to 60 , with " 1 " being the first and "60" the last. The operators knew to which treatment group the treated tooth would belong at the time of care. When one patient had more than one deciduous molar to be treated, the allocation sequence was respected, and each tooth was treated in one session, being classified in G1 (Formocresol Biodinâmica Ibiporá, Brazil) and G2 (PBS HD CIMMO ${ }^{\circledR}$ Pouso Alegre, Brazil).

The patients were anesthetized, Local anesthesia was used with 2\% lidocaine and 1: 100,000 epinephrine (Novafarma Goiânia, Brazil), and the operative field was isolated. Removal of the carious tissue, opening of the pulp chamber and hemostasis were performed. In G1, irrigation was performed with physiological saline solution, after spontaneous hemostasis, the pulp chamber was dried with sterilized cotton and formocresol was applied with modified BUCKLEY formula (1904) modified by BERGER (1965) [12], consisting of 19\% formaldehyde, 35\% cresol, $15 \%$ glycerol and water, for 5 minutes. Next, eugenol zinc oxide (IRM Dentsply ${ }^{\circledR}$ Petrópolis, Brazil) cement base was inserted and calcium hydroxide cement (Hidro C Dentsply ${ }^{\circledR}$ Petrópolis, Brazil). Composite resin (Charisma Kulzer ${ }^{\circledR}$ Heraeus Kulzer South America, São Paulo, Brazil) was used for the final restoration material.

In group 2, irrigation was performed with sterilized distilled water because the cement PBS HD CIMMO® loses its properties in a saline solution. Excess blood and distilled irrigation water were aspirated through a disposable endodontic cannula (DFL ${ }^{\circledR}$ Rio de Janeiro, Brazil), under continuous vacuum suction. PBS HD $\mathrm{CIMMO}^{\circledR}$ cement was manipulated through a sterile glass plate and spatula (Duflex ${ }^{\circledR}$ Juiz de Fora, Brazil) and was later inserted with an amalgam port (Duflex ${ }^{\circledR}$ Juiz de Fora, Brazil) into the pulp chamber and condensed with a straight amalgam condenser (Duflex ${ }^{\circledR}$ Juiz de Fora, Brazil).

The PBS HD $\mathrm{CIMMO}^{\circledR}$ cement was used as the base and, simultaneously, for final restoration (figures 1 and 2). Figure 3 uses a flowchart to shows, in a simplified manner, the methods of use in both groups.

The patients returned monthly for 12 months after pulpotomies. Clinical and radiographic exams were defined as results of treatments. In the radiographs, presence or absence of inter-radicular lesion was observed for a criterion defined as primary outcome. The radiographs were analyzed individually by the qualified researchers. In the clinical exams, the observed criteria were presence or absence of fistula and integrity of the restoration, which was defined as the secondary outcome.

The information collected from the questionnaires was transcribed into a database (Microsoft Excel® Microsoft Corporation) and analyzed statistically with the support of the software SPSS ${ }^{\circledR} 20$ for Windows (Statistical Package for Social Sciences) using the hypothesis test for two samples (Fisher's exact test) for correlation of clinical and radiographic criteria using $\mathrm{p} \leq 0.05$ for significance.

\section{RESULTS}

The present study consisted of 60 deciduous molar teeth of 32 patients. The teeth were randomly distributed 

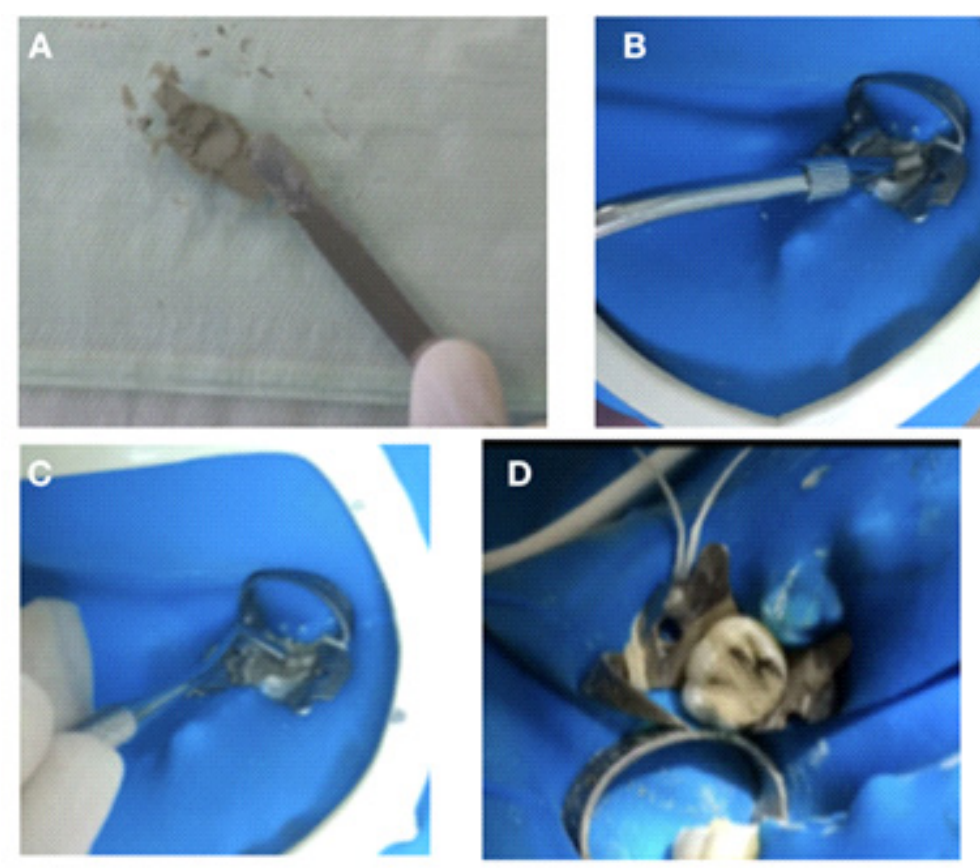
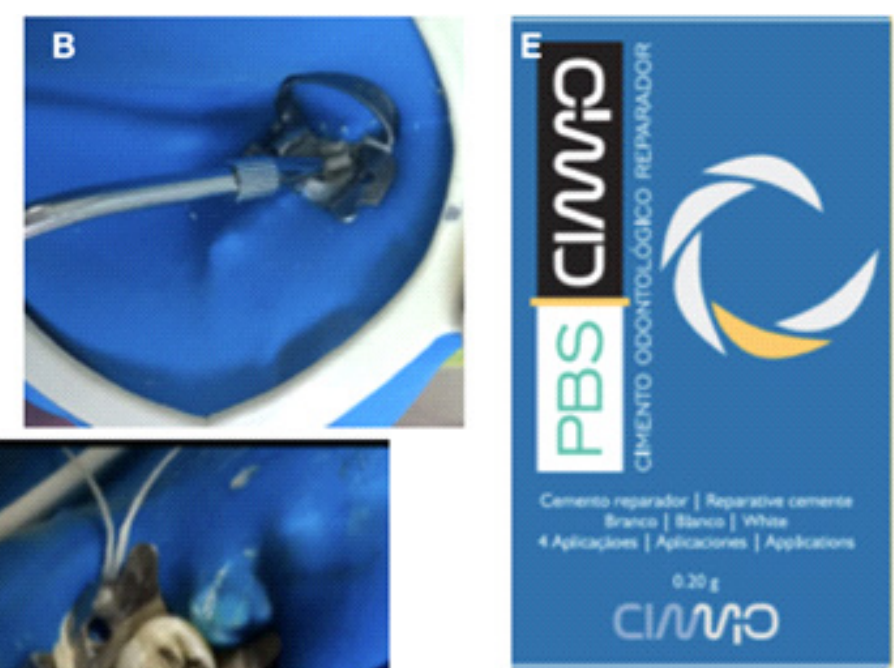

Figure 1. A) Manipulation of the cement $\mathrm{PBS}^{\circledR} \mathrm{CIMMO}$, B) Insertion of the cement into the cavity C) Condensation D) Final appearance of the cavity with the cement $\mathrm{PBS}{ }^{\oplus} \mathrm{CIMMO}$, being base, overlay and restoration, E) Cement logo.
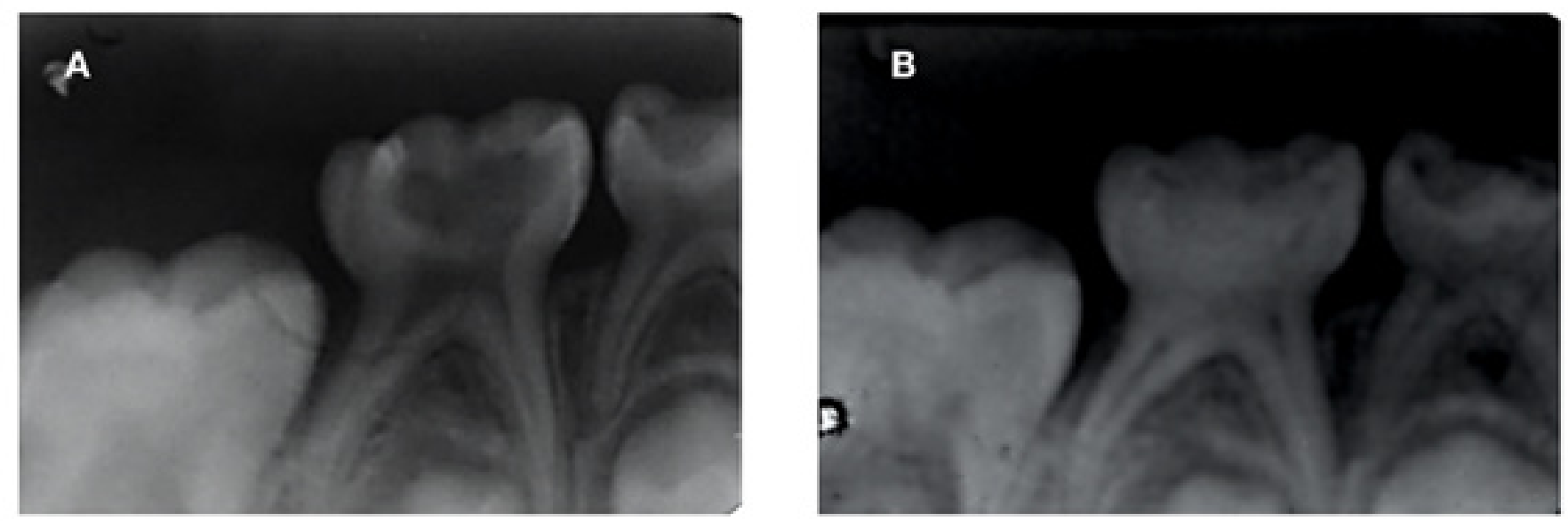

Figure 2. A) Initial radiographic aspect of element 85 with indication of pulpotomy. B) Final radiographic aspect of the element filled with PBS ${ }^{\circledR} \mathrm{CIMMO}$ as base, overlay and restoration.

as 30 teeth for $\mathrm{G} 1$ (FC) and 30 teeth for G2 (PBS HD $\left(\mathrm{CIMMO}^{\circledR}\right)$.During the study, 7 teeth from $\mathrm{G} 1$ and 3 teeth from $G 2$ were excluded because of the need to perform pulpectomy, in which the pulp presented light red (inflamed pulp) or dark bleeding (tendency to necrosis), determining senile pulp conditions; teeth that presented necrosed pulps in the accomplishment of the coronary opening; patients who did not return for clinical procedures related to the study; and patients who did not cooperate or discontinued treatment during the clinical procedure. At the end of the data collection, after 12 months, the sample consisted of 50 teeth; group 1 had 23 teeth, and group 2 had 27 teeth (CONSORT 2010 Flow Diagram).

There were 3 teeth considered as failure for group 1, and no teeth were considered as failure for group $2(p=0.090)$. Regarding the clinical aspects, the comparisons between the groups were analysis of the integrity of the restorations and presence or absence of 


\section{PULPOTOMY}

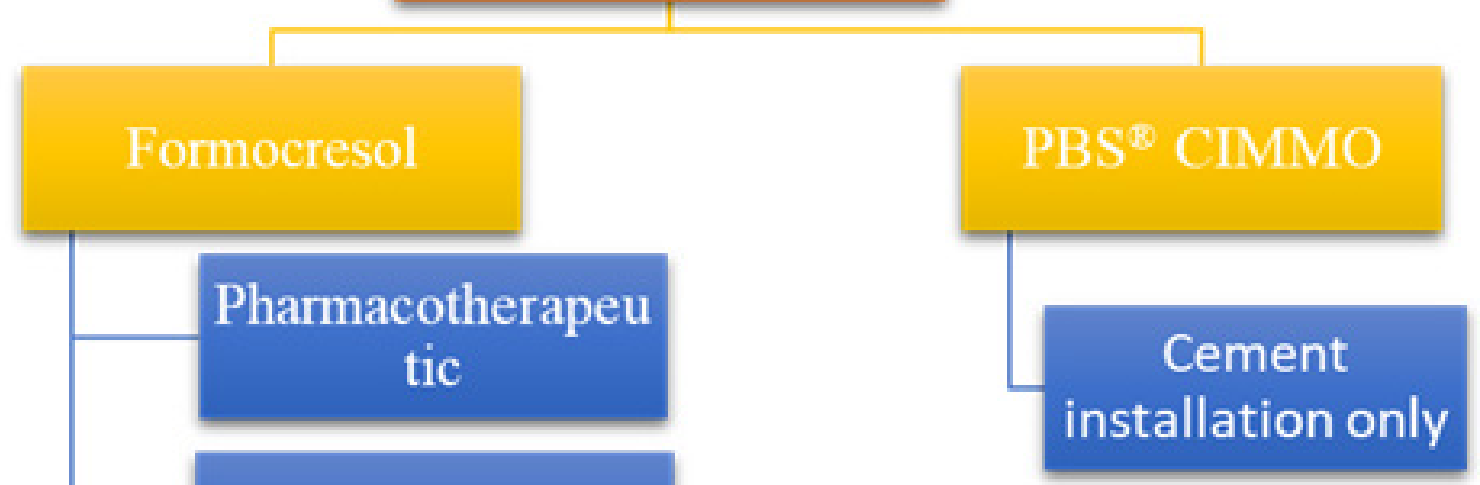

\section{Base OZE}

\section{About Calcium Hydroxide Base}

\section{Composite resin}

Figure 3. Flowchart of techniques in both groups.

Table 1. Clinical and radiograph analysis of 50 teeth with the criteria: clinical examination (Fistula and restoration integrity) and radiographic examination (lesion), $(p=0,090)$.

\begin{tabular}{|c|c|c|c|c|c|c|c|c|c|c|c|c|c|}
\hline & & \multicolumn{4}{|c|}{ Fistula } & \multicolumn{4}{|c|}{ Restoration Integrity } & \multicolumn{4}{|c|}{ Radiograph lesion } \\
\hline & & $\mathrm{n}$ & $\%$ & $n$ & $\%$ & $\mathrm{n}$ & $\%$ & $\mathrm{n}$ & $\%$ & $n$ & $\%$ & $\mathrm{n}$ & $\%$ \\
\hline \multirow{2}{*}{ Group } & G1 & 3 & $13,00 \%$ & 20 & $87,00 \%$ & 20 & $87,00 \%$ & 3 & $13,00 \%$ & 3 & $13,00 \%$ & 20 & $87,00 \%$ \\
\hline & $\mathrm{G} 2$ & 0 & $0,00 \%$ & 27 & $100,00 \%$ & 27 & $100,00 \%$ & 0 & $0,00 \%$ & 0 & $0,00 \%$ & 27 & $100,00 \%$ \\
\hline
\end{tabular}

fistula. G1 presented 3 teeth with damaged restorations and 3 teeth with fistula. The groups were compared with respect to the radiographic aspects: 3 teeth from group 1 presented interradicular lesions. G1 had 3 failures, and group 2 had no failures. In a comparison of the two groups (table 1), there were no significant differences in scores between the two groups.

\section{DISCUSSION}

The premature loss of deciduous teeth can trigger a series of injuries, such as occlusion disorders, functional and aesthetic problems [13]. The most important factor in the success of the therapy that determines the removal of the coronary pulp is the maintenance of the vitality of the 


\section{CONSORT 2010 Flow Diagram}

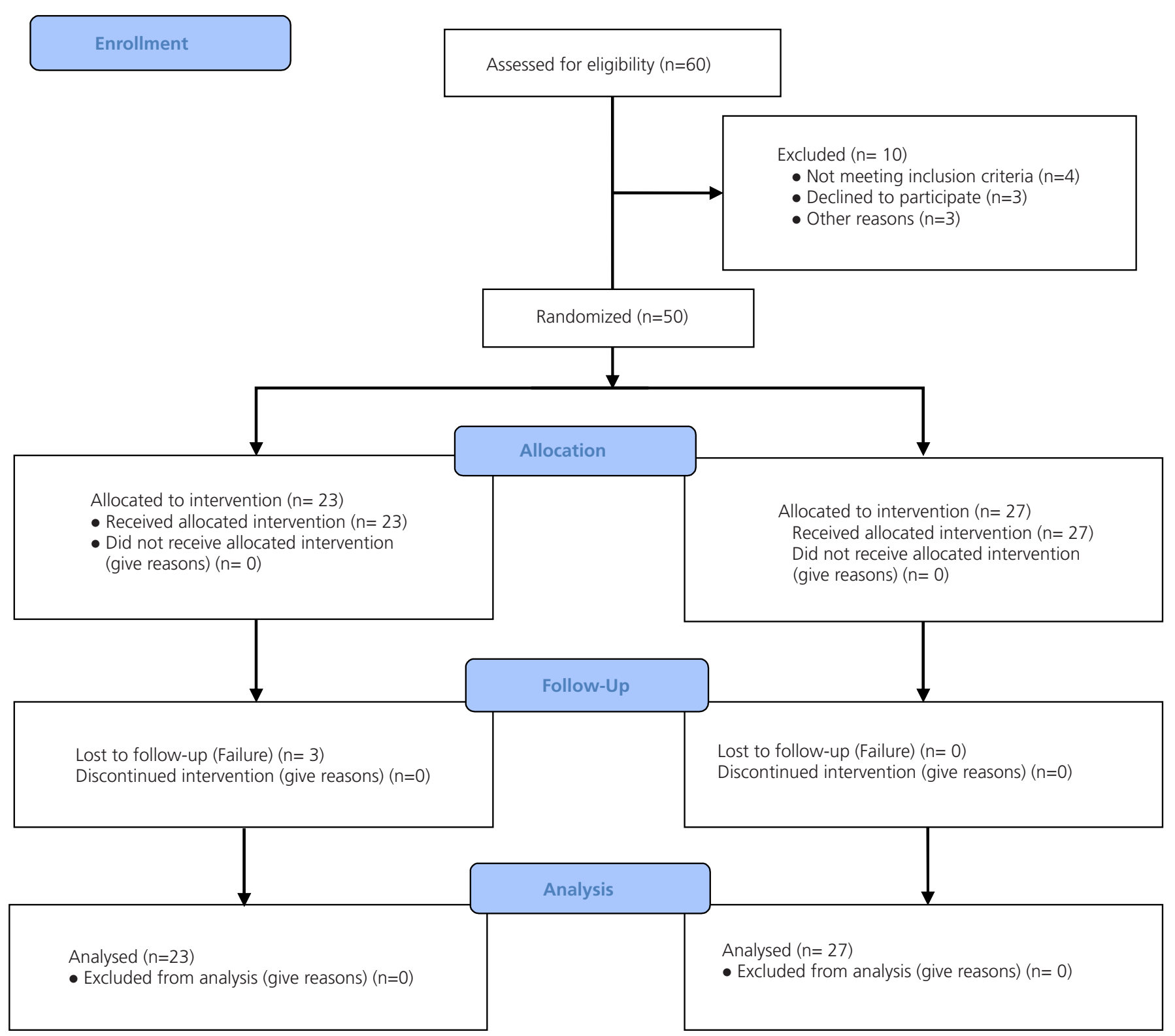

root pulp with the presence of adequate vascularization. This step is necessary for the formation and active function of odontoblasts until the subsequent natural eruption of permanent teeth [14-16]. Pulpotomy is one of the most widely accepted clinical procedures for the treatment of pulp exposed to deciduous teeth without symptoms due to the regenerative capacity of root pulp tissue after surgical amputation of the coronary pulp $[16,17]$. The present study based its conception and inclusion criteria on these concepts.
The techniques for performing pulpotomy of deciduous teeth are diverse and include electrosurgery and laser [19]. There are also pharmacotherapeutic treatments, such as formocresol, which is considered the gold standard [20, 21], and glutaraldehyde, ferric sulphate [22, 23], lyophilized bone, bone morphogenic protein, osteogenic protein, enriched collagen solutions, fully synthetic nanocrystalline hydroxyapatite paste21 and biological cements [24, 25].

In the present study, the absence of signs and clinical and radiographic symptoms were observed in 47 
teeth. There were three cases of failure for $\mathrm{G} 1$; these teeth presented interradicular lesions on the radiographs, fistulas and restorations without integrity.

The replacement of formocresol in vital pulp therapy of deciduous teeth by other material has become an emergency necessity. Formaldehyde present in the circulation can react with macromolecules, potentially causing mutagenic and cytotoxic changes in muscles, liver, kidney, heart, spleen and lung tissue, and formaldehyde is currently used by an alarming number of clinicians worldwide $[23,26,27,28,29,30]$. The present study undertook a comparison of techniques. The FC technique was used as the control group, and the PBS HD CIMMO® was used as the intervention technique. This material was used shortly after removal of the coronary pulp; the fourstep technique was reduced to one; this cement is both therapeutic, due to the two properties (bioactivity and biocompatibility), as well as base and restoration (single material), as dispensed with the use of other materials $[6,7]$.

The difficulties of the present study are related to the process of performing these treatments due to the physical and psychological aspects. The time of execution of the two techniques was measured: G1 required, on average, one hour and fifteen minutes per tooth to perform the entire procedure, while $\mathrm{G} 2$ took thirty-five minutes. G2 (PBS HD $\mathrm{CIMMO}^{\circledR}$ ) optimized the execution time of the technique, which is relevant in relation to the decrease of the physical and emotional stress of the patient and the professional.

The statistical analysis determined that there was no significance between $\mathrm{G} 1$ and $\mathrm{G} 2$ in the treatments performed; however, the possibility of presenting material that replaced the gold standard for pulpotomies of deciduous teeth using the cement PBS HD CIMMO® is determined by three situations: the bioactive action of the cement by the biocompatibility and bioactivity, not requiring such pharmacotherapeutics as $\mathrm{FC}$, resistance of the cement, ability to be both base and restoration, presenting resistance to compression supporting the masticatory forces, and having alkaline $\mathrm{pH}$, preventing microbial infiltration. All 27 teeth treated with PBS cement remained intact after 12 months of accompaniment, as defined in analyses of scores regarding clinical and radiographic success.

PBS HD CIMMO $®$ cement is considered an option to be used as base and restoration in pulpotomies of deciduous teeth. The present study facilitated the learning curve, with success being achieved in all cases performed. Furthermore, longitudinal studies should be performed to demonstrate a significant association between these groups. The PBS HD CIMMO ${ }^{\circledR}$ cement is considered an option to be used as a single element in pulpotomies of deciduous teeth.

\section{CONCLUSION}

The relevance of the present study is defined by the proposed protocol that used cement with unique function in the pulpotomy, optimized and facilitated the procedure. The rehabilitation was due to cement properties, biocompatibility and bioactivity. The PBS HD $\mathrm{CIMMO}^{\circledR}$ cement is considered an option to be used as a single element in pulpotomies of deciduous teeth.

\section{Collaborators}

The master student MOYSÉS FV was responsible for writing the article and for pre- and postoperative follow-up. The coorientation, composition and critical review of the articles were carried out by Professor VEIGA DF. The Professors: PEREIRA MJ, DOMINGHETE MHL, PAZZINI CA, PEREIRA ACJ followed the clinical procedures and performed postoperative evaluations. SILVA NETO JD, was the study's supervisor and responsible for evaluating clinical procedures and postoperative evaluations, was also responsible for the composition and critical review of the article.

\section{REFERENCES}

1. Celik BN, Mutluay MS, Arikan V, Sari S. The evaluation of MTA and Biodentine as a pulpotomy materials for carious exposures in primary teeth. Clin Oral Investig. 2019;23:661-666. https://doi.org/10.1007/s00784-018-2472-4

2. Ibricevic $\mathrm{H}, \mathrm{Al}$-Jame $\mathrm{Q}$. Ferric sulfate as pulpotomy agent in primary teeth: twenty month clinical follow-up. Journal of Clinical Pediatric Dentistry. J Clin Pediatr Dent. 2000;24:269-72. https://doi.org/10.17796/jcpd.24.4.d7u6405nw1132705

3. Srinivasan D, Jayanthi M. Comparative evaluation of formocresol and mineral trioxide aggregate as pulpotomy agents in deciduous teeth. J Dent Res. 2011;22:385-90. https://doi.org/10.4103/0970-9290.87058

4. Simancas-Pallares MA, Díaz-Caballero AJ, Ricardo Luna-LM. Mineral trioxide aggregate in primary teeth pulpotomy. A systematic literature review. Med Oral Patol Oral Cir Bucal. 2010;15:942-46. https://doi.org/10.4317/medoral.15.e942 
5. Junqueira MA, Cunha NNO, Caixeta FF, Marques NCT, Oliveira TM, Moretti ABDS, Cosme-Silva L, Sakai VT. Clinical, Radiographic and Histological Evaluation of Primary Teeth Pulpotomy Using MTA And Ferric Sulfate. Braz Dent J. 2018;29(2):159-165. https://doi.org/10.1590/0103-6440201 801659

6. Boczar RML, Veiga DF, Juliano $Y$, Schnaider TB, Silva Neto JD. Bioceramic cement in endodontic fillings: a randomized clinical trial. J Dent Health Oral Disord Ther. 2020;11(3):78-84. https://doi.org/10.15406/jdhodt.2020.11.00523

7. Silva SR, Silva Neto JD, Schnaider TB, Viega DF, Novo NF, Mesquita M Filho, Ferreira LM. The use of a biocompatible cerment in endodontic surgery. A randomized clinical trial. Acta Cir Bras. 2016;31(1):422-7. https://doi.org/10.1590/S0 102-865020160060000010

8. Malkondu O, Kazandag KM, Kazazoglu E. A review of Biodentine a Dentine replacement Contemporary Material and Repair. Biomed Res Int. 2014;1-10. https://doi.org/10.11 55/2014/160951

9. Silva SRD, Filho IJZ, Silva Neto JD. Incomplete rhizogenesis and necrosis treated with PBS® HP cement synthetic barrier: case report. J Dent Health Oral Disord Ther. 2018;9(3):205208. https://doi.org/10.15406/jdhodt.2018.09.00379

10. Silva Neto JD, Schnaider TB, Gragnani A, Paiva AP, Novo NF, Ferreira LM. Portland cement with additives in the repair of furcation perforations in dogs. Acta Cir Bras. 2012;27:809814. https://doi.org/10.1590/s0102-86502012001100011

11. Silva SR, Silva Neto JD, Novo NF, Veiga DF, Schnaider T, Ferreira LM. Portland cement versus MTA as a root-end filling material. A pilot study. Acta Cir Bras. 2015;30(2):160-164. https://doi. org/10.1590/S0102-865020160060000010

12. Coll JA, Seale NS, Vargas K, Marghalani AA, Al Shamali S, Graham L. Primary tooth vital pulp therapy: a systematic review and meta-analysis. Pediatr Dent. 2017; 15;39(1):16-123.

13. Nayak UA, Wadhwa S, Kashyap N, Prajapati D, Mahuli AV, Sharma R.Knowledge and practice of, and attitudes toward, pulp therapy in deciduous teeth among pediatric dentists in India. J Investig Clin Dent. 2017;1(1):1-5. https://doi.org/10. $1111 /$ jicd. 12284

14-Bolette A, Truong S, Guéders A, Geerts S.The importance of pulp therapy in deciduous teeth. Rev Med Liege. 2016;71(12):567-572.

15-Purohit RN, Bhatt M, Purohit K, Acharya J, Kumar R, Garg R. Clinical and Radiological Evaluation of Turmeric Powder as a Pulpotomy Medicament in Primary Teeth. Study. Int J Clin Pediatr Dent. 2017;10(1):37-40. https://doi.org/10.5005/jpjournals-10005-1404

16. Coll JA, Seale NS, Vargas K, Marghalani AA, Al Shamali S, Graham L. Primary tooth vital pulp therapy: a systematic review and meta-analysis. Pediatr Dent. 2017;39(1):16-123.

17. Ozmen B, Bayrak S. Comparative evaluation of ankaferd blood stopper, ferric sulfate, and formocresol as pulpotomy agent in primary teeth: A clinical study. Niger J Clin Pract. 2017;20(7):832-838. https://doi.org/10.4103/1119-3077.197 022
18. Juneja P, Kulkarni S.Clinical and radiographic comparison of biodentine, mineral trioxide aggregate and formocresol as pulpotomy agents in primary molars. Eur Arch Pediatr Dent. 2017;18(5):271-278. https://doi.org/10.1007/s40368-017-02 99-3

19. Parisay I, Ghoddusi J, Forghani M. A review on vital pulp therapy in primary teeth. Iran Endod J. 2015;10(1):6-15.

20. Al-Dlaigan YH. Pulpotomy medicaments used in deciduous dentition: an update. Contemp Dent Pract. 2015;16(6):486503. https://doi.org/10.5005/jp-journals-10024-1711

21-Lewis B. The obsolescence of formocresol. Br Dent J. 2009;207(11):525-528. https://doi.org/10.1038/sj.bdj.2009. 1103

22. Ansari G, Ranjpour M. Mineral trioxide aggregate and formocresol pulpotomy of primary teeth: a 2-year follow-up. Int End J. 2010;43:413-418. https://doi.org/10.1111/j.1365-25 91.2010.01695.x

23. Ibricevic $\mathrm{H}$, Al-Jame Q. Ferric sulfate as pulpotomy agent in primary teeth: twenty month clinical follow-up. J Clin Pediatr Dent. 2000;24:269-72. https://doi.org/10.17796/jcpd.24.4. d7u6405nw1132705

24. Farrokh Gisoure E. Comparison of Three Pulpotomy Agents in Primary Molars: A Randomised Clinical Trial. Irã Endod J. 2011;6:11-14.

25. Niranjani K, Prasad MG, Vasa AA, Divya G, Thakur MS, Saujanya K.Clinical Evaluation of Success of Primary Teeth Pulpotomy Using Mineral Trioxide Aggregate(®), Laser and Biodentine(TM)- an In Vivo Study. J Clin Diagn Res. 2015;9(4):35-7. https://doi.org/10.7860/JCDR/2015/13153.5823

26. Olatosi OO, Sote EO, Orenuga OO.Effect of mineral trioxide aggregate and formocresol pulpotomy on vital primary teeth: a clinical and radiographic study. Niger J Clin Pract. 2015;18(2):292-6. https://doi.org/10.4103/1119-3077.151 071

27. Jiang $\mathrm{S}, \mathrm{Wu} \mathrm{H}$, Zhang CF. Partial pulpotomy of immature teeth with apical periodontitis using bioceramics and mineral trioxide aggregate: a report of three cases. Chin J Dent Res. 2016;19(2):115-20. https://doi.org/10.3290/j.cjdr.a36182

28. Shafie L, Barghi H, Parirokh M, Ebrahimnejad H, Nakhae N, Esmaili S. Postoperative pain following pulpotomy of primary molars with two biomaterials: a randomized split mouth clinical trial. Iran Endod J. 2017;12(1):10-14. https://doi.org/10. 22037/iej.2017.0

29. Kahl J, Easton J, Johnson G, Zuk J, Wilson S, Galinkin J. Formocresol blood levels in children receiving dental treatment under general anesthesia. Pediatr Dent. 2008;30(5):393-399.

30. Hugar SM, Kukreja P, Hugar SS, Gokhale N, Assudani H. Comparative Evaluation of Clinical and Radiographic Success of Formocresol, Propolis, Turmeric Gel, and Calcium Hydroxide on Pulpotomized Primary Molars: A Preliminary Study. Int J Clin Pediatr Dent. 2017;10(1):18-23. https://doi.org/10.5005/ jp-journals-10005-1400

Received on: $26 / 11 / 2018$ Final version resubmitted on: 2/3/2019 Approved on: 22/3/2019 